\title{
Implementation trajectories of environmental education for sustainable development in formal, non-formal and informal education based on eduScrum project management methodology
}

\author{
Natalya Ryazanova ${ }^{1}$, Vladimir Naumov ${ }^{2}$, Natalia Kamennykh ${ }^{2}$ \\ ${ }^{1}$ Moscow State Institute of International Relations (MGIMO University), Department of Integrated \\ International Ecological Problems and Wildlife Management, 119454, 76 Vernadskogo prospect, \\ Moscow, Russia \\ ${ }^{2}$ Moscow Timiryazev Agricultural Academy, Department of soil science, Geology and landscape \\ studies, 127550, 49 Timiryazevskaya st., Moscow, Russia
}

\begin{abstract}
The aim of the study is to study approaches to localization of the topic of SDG in higher education in Russia and some tracks for implementation of environmental education for sustainable development (EESD). The objectives were: to formulate a goal setting for each of the approaches; to develop a methodology for the introduction of the SDG ideology into EESD; to implement the personal and collective role of research team members in working on the project; to create effective collaborations and introduce an interdisciplinary approach; to be able to present the results obtained in a visual and analytical form; to expand the professional outlook of environmentalists, to form a worldview based on the development of competencies for sustainable development. The research methodology in formal education was based on the hypothesis that modern environmental education should be based on the triad of SDG clusters, and all didactic units of university programs should be filled with this ideology. The information approach was implemented through the introduction of project laboratory technologies, case studies and youth models. Strategically, the higher education institutions participating in the experiment developed a methodology for tracking higher education for sustainable development and introduced methods for working with the subjects of SDG.
\end{abstract}

\section{Introduction}

The topicality of the research consists in adaptation of the subjects of Education for Sustainable Development (ESD) to different forms, methods of teaching and different didactic units in Russia [1]. The tradition of using an interdisciplinary approach in its modern understanding (integration of economic, social and environmental knowledge and information about the research subject) is only emerging. In the first years, a project 
approach to education is being introduced, which in higher education is introduced only in a few universities on a permanent basis and is going through the formative stage.

Most developed countries have entered the ESD process using the UNESCO recommendations to develop competencies for sustainable development. Russia supports the general trend in this direction, but there are no requirements for their introduction and quantitative indicators and a road map for their achievement. There is no localization of these requirements in state documents [2], no special national methods have been developed. The author of this work tends to see this not as an obstacle, but as a huge opportunity for creative independent work of research schools across the country, a deep exchange of experience in this direction and a positive assessment of the existing and future contribution of Russian pedagogical science to the global ESD piggy bank.

The research hypothesis. The modern volatile "VUCA" world does not allow teachers to build long chains of learning and to adapt them to the needs of the labor market for a long time. Employers have no time to wait, then adapt and give time to adapt a young employee to the rapidly changing demands of the state economy. The modern learning process in the university needs the introduction of Agile technologies and the project learning environment of eduScrum. For this purpose, it has been proposed to introduce the project approach in various types of training and extracurricular activities. Students are immersed in the themes of the SDG, conduct research on environmental issues, and determine, at the same time, what tasks the SDG correspond to, study the qualitative and quantitative parameters of the possibility of achieving the SDG by various methods. Teachers and employers should be able to assess the product (educational) result and develop mechanisms to work with it as flexibly as possible [8].

The novelty of the work is to develop a flexible functional block (consisting of blocks) model of the project approach in education for sustainable development. Students studying in the field of environmental and nature management training should get a relatively perfect and simple learning mechanism, which can be easily transformed into tasks, ways of their solution and the final expected product (educational result). Such an approach will allow teachers to input relevant baseline data, set a research objective quite simply, and only minimal participation (direction) in the learning process. The model should contribute to the maximum flexibility of the learning process, be understandable for teachers, students and potential employers, it is they who should be able to monitor the process of formation of future specialists and assess the final result in terms of the quality of skills.

The work is carried out according to Adgile methodology in the educational environment on the basis of the approach to the formation of project work skills using eduScrum project management methodology [3-5]. The scientific and pedagogical activity has been implemented by identifying the range of modern professional tasks of an ecologist and creating methodological recommendations for the implementation of the PP MFB within the framework of educational and extra-curricular activities. Practical pedagogical activity was supported by the creation of Road Maps and soft tools to support research groups to achieve them in time, and such competencies as communication, teamwork, critical thinking and creativity ("4K") were pumped up.

The paper presents various approaches to the formation of the MTF PP for the main educational process, for club and club work of students during after-hours, for major games. The main forms of presentation of results: design laboratories, youth models of international and Russian processes, business games, simulations, etc.).

The first results of the experience of implementation of the MTF PP in educational and enlightening processes are presented. Qualitative assessments of students' skills received by three categories of mentors are given: public administration sector, business sector, science sector. Representatives of these three sectors, after each event conducted using the MTF 
PP, gave feedback and practical recommendations to students and their teachers to improve the Model of the project educational environment and its precise adaptation to the tasks.

\section{Methods and materials}

The eduScrum project management methodology was introduced in 2011 in the Netherlands and is now presented as an implemented technology in 36 countries worldwide. The eduScrum method has evolved from numerous developments in various fields of activity, which have adopted this approach from the IT sector and managed to adapt it to their own needs. [6,7]. "The agile teaching/learning methodology (ATLM) was developed back in 2004, when Agile was adapted to education methods [8,9].

In the formal approach the technology was implemented twice, within the framework of the profile discipline Basics of Nature Management in the form of setting two educational tasks. For an example of working with the method, one of the educational tasks was considered.

The educational objective: Comprehensive multi-criteria evaluation of the implementation of national projects to achieve sustainable development in the Russian Federation: analysis of the current state and potential of each federal district.

Objectives: To carry out a comprehensive analysis of sustainable development goals and national projects of the Russian Federation; to relate national projects to world development priorities (SDG); to develop a road map for achieving sustainable development goals and strategic objectives of national projects of the Russian Federation for each federal district.

Training and research tasks: Inventory, selection and justification of the selection of functional CSD clusters. Analysis and distribution by functional cluster of national projects of the Russian Federation. Analysis of the current state of the federal district and responsible government agencies, taking into account the natural resource potential. Analysis of the potential for achieving the targets of the National Projects in accordance with complementary SDGs. Creation of a functional model for achieving the SLM. Formation of criteria for assessing the achievement of national projects and SDGs within the federal district. Creation of a road map for achieving sustainable development in the federal district.

In the informal approach, the technology was implemented many times, for example, in the preparation of student and not only conferences, models, round tables, when the organizing committee of the event formulated an order to update the Agenda-2030 within the theme of the event. For example, we will demonstrate a research task, which does not have any obvious signs of training, but significantly expands the horizons of participants of project teams.

Research task: Creation of a World Water Forum Youth Model based on the objectives of the Sustainable Development Goals.

Purpose of work: 1. To create six thematic teams (as in the original event): Climate, People, Growth, Quality, Ecosystems, Guidance. Working out and filling the thematic content of each thematic section (in our case - the game team). Publication of Analytical materials on the topic of Model work.

Research tasks: 2. Distribution of authority for the content of work within your team.

3. Identification of a list of source documents and information sources for training on the subject. 4. Consultation and cooperation with the official bodies in charge of this area of work in the region. 5. Working meetings of each group (students + local government curators) to coordinate the material received and determine the quality and quantity of information that will remain in the final presentation at the event. 6. Updating of initial and 
final information for the region. 7. Development of targeted recommendations for the "Customer".

In the informal approach the technology was also implemented more than 10 times. The role of the Customer was played by governors or regional governments, state executive bodies (Ministries of Education, Natural Resources and Environment, etc.), Forum Organizing Committees. The method was implemented in the form of project laboratories, youth models of international and Russian processes, business games, simulations, etc.). each time teams from different universities of the country were invited to participate in the games. Students of different faculties find application of their professional knowledge, which allows to implement the sustainable development approach when three clusters (economy, ecology, society) are actualized and the developed solutions help to achieve the SSD in an integrated manner.

Table 1. Technology of project activities implementation in all types of training

\begin{tabular}{|c|c|c|c|c|}
\hline $\begin{array}{l}\text { Type of } \\
\text { training }\end{array}$ & $\begin{array}{c}\text { Product } \\
\text { Owner } \\
\text { (Customer) }\end{array}$ & $\begin{array}{l}\text { SCRUM } \\
\text { Master }\end{array}$ & $\begin{array}{l}\text { Delivery } \\
\text { Team }\end{array}$ & Educational result \\
\hline 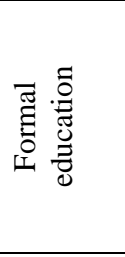 & $\begin{array}{l}\text { The state, } \\
\text { prospective } \\
\text { employers }\end{array}$ & $\begin{array}{l}\text { A teacher in } \\
\text { cooperation with } \\
\text { representatives of a } \\
\text { conditional employer } \\
\text { (from government } \\
\text { agencies, business, } \\
\text { science and so on) }\end{array}$ & $\begin{array}{l}\text { Study groups } \\
\text { divided into work } \\
\text { teams (mini-groups) }\end{array}$ & $\begin{array}{l}\text { Analytical materials } \\
\text { (notes), coursework, } \\
\text { research report, } \\
\text { final qualification } \\
\text { paper }\end{array}$ \\
\hline 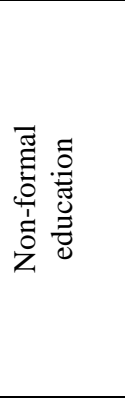 & $\begin{array}{l}\text { Student clubs, } \\
\text { clubs, } \\
\text { informal } \\
\text { communities, } \\
\text { media groups, } \\
\text { etc. }\end{array}$ & $\begin{array}{l}\text { Event Organizing } \\
\text { Committee }\end{array}$ & $\begin{array}{l}\text { Students from as } \\
\text { many departments, } \\
\text { faculties, institutes } \\
\text { as possible; students } \\
\text { of different courses, } \\
\text { of different ages, } \\
\text { with different } \\
\text { scientific and life } \\
\text { experience, with } \\
\text { different ratings }\end{array}$ & $\begin{array}{l}\text { Media analytics, } \\
\text { publication of the } \\
\text { event material, } \\
\text { formation of the } \\
\text { community } \\
\text { interested in } \\
\text { development and } \\
\text { maintenance of the } \\
\text { theme of students } \\
\text { and teaching } \\
\text { community }\end{array}$ \\
\hline 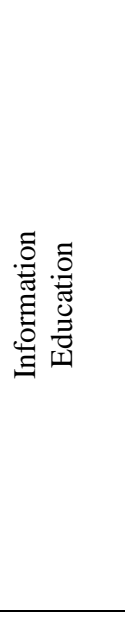 & $\begin{array}{l}\text { State } \\
\text { government } \\
\text { bodies, } \\
\text { executive } \\
\text { authorities, } \\
\text { business } \\
\text { structures, } \\
\text { scientific } \\
\text { institutions, } \\
\text { forum } \\
\text { organizing } \\
\text { committees } \\
\text { and others }\end{array}$ & $\begin{array}{l}\text { Customer } \\
\text { representative - a } \\
\text { person authorized to } \\
\text { interact directly with } \\
\text { the process } \\
\text { participants, who is } \\
\text { able to correctly } \\
\text { orient and advise the } \\
\text { players in the guiding } \\
\text { documents, targets } \\
\text { and the expected } \\
\text { result of the } \\
\text { simulation }\end{array}$ & $\begin{array}{l}\text { Students of different } \\
\text { higher education } \\
\text { institutions of the } \\
\text { country studying in } \\
\text { different areas of } \\
\text { training. This } \\
\text { activity is not } \\
\text { always taken into } \\
\text { account in the } \\
\text { current educational } \\
\text { process, is poorly } \\
\text { integrated into it } \\
\text { and will not be } \\
\text { appreciated by the } \\
\text { university from } \\
\text { which the team } \\
\text { arrived. }\end{array}$ & $\begin{array}{l}\text { Development of } \\
\text { strategies, plans, } \\
\text { road maps, strategic } \\
\text { vision offers for the } \\
\text { customer }\end{array}$ \\
\hline
\end{tabular}

For example, a project task is given, which is not an educational one, but an expanding horizon; it allows to look at the problem much wider than it is seen by the performers at the 
moment, to attract experience and knowledge of various professionals and helps to discover new sources of information and technologies of project work (Table 1).

Project task: Creation of the Youth Model of the Project Office "UN Sustainable Development Goals: the Baikal Dimension". Baikal-2030 Youth Strategy.

The objective of the IMPO (Youth Project Office Model) is to identify a focus on the complex problems related to environmental management in the regions and develop a road map to overcome them for each of the thematic working groups to achieve the UN sustainable development goals.

Project Objectives: To identify focus on complex environmental issues in the regions and develop a road map to address them for each of the thematic working groups to achieve the UN sustainable development goals:

1. Examine the peculiarities of the territorial situation and natural and geographic opportunities for economic and bio-resource development; 2. To propose additional measures for introduction of innovative approaches in the economic structure of the region to preserve and multiply the existing potential and opportunities to solve complex problems for sustainable development of the regions, while maintaining environmental quality indicators at a high level; 3. Analyze and highlight legal, economic, scientific, technical and technological measures already being implemented in the field of environmental security in the form of a decision matrix for each of the thematic working groups; 4. To propose additional measures to introduce sustainability principles into the economic structure of the region; 5. Weigh the existing short- and long-term natural and anthropogenic risks for the region; 6. Formulate criteria for public assessment and propose a basis for development of tools for long-term socio economic and ecological safety in the region.

\section{Results}

As a result, the Functional Block Model of the project approach was created. At realization of formal training technologies Agile and project educational environment eduScrum are introduced. Analytical notes, term papers and final qualifying papers have been received. In non-formal education, students were formed skills to create media analytics, published materials of events, formed communities interested in developing and maintaining the theme of students and teaching community. In the informal approach there were created strategies and plans of regional, federal and thematic refraction and introduction of CSD ideology, as well as road maps for their achievement; local communities and young people have formed a practical skill of integrated approach to regional problems based on the triad of clusters: economy, ecology, society.

Involvement of young people in the real social and political process in the region for active and inclusive participation of local communities in collective decision making to improve the basic indicators of people's lives.

\section{Discussion}

The difficulty of attracting specialists from the real sector of the economy for two reasons should be noted as a constraint in formal education: many of them do not possess methodological and teaching qualities at all and do not have free time convenient for the schedule of students in these disciplines. In informal and non-formal learning, there are other limitations: teams of players need to be so interested in the topic and the process of modeling that they will develop in a short time and will be able to work, so that none of the players will "pull the blanket over", so that players will not be considered with free time. As a rule, 1.5 months before the event, all players are deprived of the opportunity to 
systematically study and rest, i.e. they find themselves in the most stressful situation. But, "survived" in these project youth models claim to more serious work!

\section{Conclusions}

The role of expert jury in all kinds of design works is performed by representatives of potential employers, who give an independent assessment of the quality of work performed and help to constantly update the agenda, guiding documents and materials, the order for the final result. In their opinion, the Functional Block Model of the Project Approach (FBM $\mathrm{PP}$ ) has already been created and is functioning quite successfully. $4 \mathrm{~K}$ competences are also being successfully formed: communication, teamwork, critical thinking and creativity.

In general, it has been shown that Adgile methodologies in the educational environment on the basis of the project work skills development approach with the application of eduScrum project management methodology proved to be very effective and are very positively perceived by employers, as they obviously form practical skills of graduates, which allows to integrate their real current work process virtually seamlessly (seamless technology). For example, such technology implemented by the Laboratory of Geoecology and Sustainable Nature Management of the Moscow State Institute of International Relations of the Russian Ministry of Foreign Affairs has allowed graduates to be employed for more than 5 years in the Project Offices and consulting agencies of the Big Four (for environmental consulting projects) represented in Russia.

\section{References}

1. A.N. Zakhlebnyy, E.N. Dzyatkovskaya, BSU, 2, 43-53 (2015).

2. T.A. Lanshina, V.A. Barinova, A.D. Loginova, E.P. Lavrovsky, I.V. Ponedelnik, BIO, 1, 207-224 (2019)

3. A. Sureka, M. Gupta, D. Sarkar, V. Chaudhary, 1st IWCM for CE, pp.72-78. (2015).

4. Z. Masood, R. Hoda, K. Blincoe, J. of Syst.and Softw, 10 (1), 501-510 (2018).

5. I. Noguera, A-E. Guerrero-Roldan, R. Maso, Comp.and Ed., 1(1), 110-129 (2018).

6. M. Cubric, Int. J. of Management Education, 11(30), 119-131 (2013)

7. L. Tverdostupova, LP, 5, 22-28 (2016)

8. M.A. Manokin, A.R. Ozhegova, E.A. Shenkman, University Management: Practice and Analysis, 4, 83-96 (2018)

9. A. Chun, LNCS - Advances in Web-Based L, 8, 11-18 (2004) 